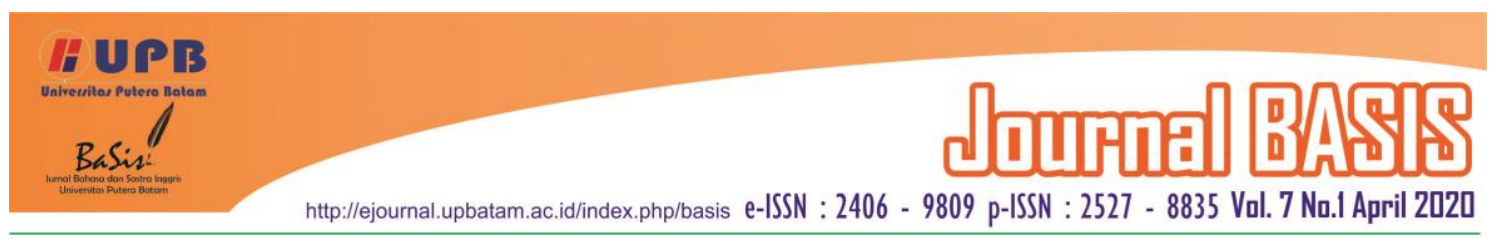

\title{
EXPLORING INDONESIAN-ENGLISH TRANSLATION SHIFT IN JOKOWI'S IMF WORLD BANK 2018 SPEECH
}

\author{
Diana Fahrun Nisya' \\ Universitas Airlangga (UNAIR), Surabaya, Indonesia \\ dianafn0108@gmail.com
}

\begin{abstract}
This paper investigated the Indonesia-English translation shift in Jokowi's Speech at the opening of the Annual Meeting Plenary of IMF-World Bank 2018. This study seek to examine the way translator applied translation shift in the process transferring message from SL to TL using Catford's translation shift and to what extent the effectiveness of its use. Accordingly, the frequency and typology were measured. This study utilized qualitative method which indicated words, phrases and sentences in describing the study. Jokowi's speech transcript at IMF-World Bank 2018 was the main subject of this study, where the Indonesia text was specifically retrieved from the official website of the Secretary Cabinet of Republic Indonesia and the English translation transcript was obtain from the Infopublik's website of Directorate General of Information and Public Communication. Initially, in the process of classification, Catford's translation shift theory (1995) was applied to rank and analyze the equivalence of Indonesia-English translation text. The result shows that all types of translation shift were found in English translation text with different number of frequency. However, the most dominant category appeared within the English translation text is class shift as much as 34 in a total, followed by unit shift 23 times and structural shift 17 times in a total. Those findings summarized that translation shift is inevitable in the case of translation process because every language has its own nature and variation that finally force the translator to deviate the language whenever she/he might transfer one language to another language and maintain the message of the source language.
\end{abstract}

Keywords: Catford's Translation Shift; Indonesia-English Translation; Jokowi's Speech Text

\section{INTRODUCTION}

Translation always started from th e interpretation of the meaning of the $\mathrm{w}$ ord, and proceeded from the adaptation to the context. According to Catford (1965) as cited in Munday (2016), translation is substitution of textual content in one language (SL) by equal textual information in other language (TL). It means the translator need to replace the material in source text (SL) correspond with target text (TL). In translating a text, translator has the authority to make some changes or modification in order to obtain an accurate meaning and equivalent expression in the target text, so that it requires advanced skill in understanding both SL and TL. Shifting SL into TL can be used as one of translation strategies to acquire equivalent meaning in the process of delivering information from SL. Translation shift is primarily necessary in case certain words, phrases, or sentences of SL are not available in the TL, shifting is finally the solution by changing into an equivalent word which has similar sense of meaning or still maintaining the message of the TL itself. 
However, translation shift is considered an old-translation method unfortunately still there are a lot of translators use this kind of method not only to transfer certain word from TL to SL but to transfer suitable meaning and message with modification since there is such lexical unavailability in both SL and TL. In this case, translating speech may be a challanging thing for translators since they need to transfer the right message of what the speaker has been delivered in order to avoid social controversy and misunderstanding. So that, translator is required enough skill to find suitable words, phrases or sentences that convey the same message between SL and TL. Translation shift help translator to technically deliver accurate information and still carry the message of the source language.

\section{LITERATURE REVIEW}

The principle of shifting has helpe $\mathrm{d}$ us much to learn how to narrow down a unit ofdifferent levels to create interest ing structures. Munday (2016) noted that translation shift is the linguistic changes that occur when translating the source text to the intended text. The term shift is originated from Catford's work entitle A Linguistic Theory of Translation (1965) developed from Firthian and Hallidayan model. Catford (1965) reported that shifting well understood as language modification made from formal correspondence in the process of moving from the source language to the target language. Shifts happen whenever the source language text is altered into different grammatical or phonological material in the target language text. Catford's concept aims at examining language in terms of structural and contextual meaning, also a number of levels and ranks as communication material.
Catford (1965) considers two kinds of shift: (1) shift of level and (2) shift of category.

1) A level shift means anything manifested in grammar of one language and lexis in another vice versa, e.g.

SL: John has stopped smoking.

TL: John sudah berhenti merokok.

2) Catford (1965) in most of his works suggested category shift into four subdivided types as in the following discussion:

a. Structural shifts: It is the most common and mostly requires a grammatical structure change. For example,

SL: stolen jewelry

TL: perhiasan yang dicuri

b. Class shifts: It includes change from one part of speech to another. For example,

SL: $\underline{\text { mechanical engineering }}$ (adjective)

TL: teknik mesin (noun)

c. Unit shifts or rank shifts: It is a linguistic changes of one language that refers to different hierarchal linguistic unit such as sentence, clause, word, etc. For example,

SL: gravity (word)

TL: gaya tarik bumi (phrase)

d. Intra-system shifts: It is a shift occurs when the SL and TL have roughly the same structure but the translation requires a specification of noncorresponding word in TL scheme. (Catford, 1965). For example,

SL: $\underline{\text { Cars }}$ in United States are very expensive

TL: Mobil-mobil di Amerika sangat mahal. 
This research focused on the translation shift found in the English translation transcript of Jokowi's speech in the opening of the Annual Meetings Plenary of IMF-World Bank 2018. Moreover, this research attempt to examine Jokowi's English transcript predominantly on application of translation shifts based on Catford's theory (1965) as mentioned previously.

In recent years, translation study had obtained much attention and interest from many scholars since translation considered significant in the development of technology, business, science, etc which is inevitable from human life in facing the transmission phase of social communication. Translation shift come in context as another solution for translator in the process of transferring message from the source language to target language without losing its significant nature of the source language. Subsequently, researcher from any part of the world tried to contribute to such field of study and gradually increase over time. To support this current studies, researcher particularly incorporates some previous studies in order to inspire this current study and contribute to the field of translation study.

A study conducted by Herman (2014) entitled "Category Shifts In the English Translation of Harry Potter and the Philosopher's Stone Movie Subtitle into Indonesia: An Applied Linguistics Study". This study mainly focused only on the Category Shift used in Harry Potter and the Philosopher's Stone Movie and its Indonesia subtitle. it came up with two research objectives; (1) to figure out the types of Catagory shift and (2) to figure out the most frequent type of translation shift used in translating the Indonesia subtitle in such movie. The findings revealed that all kinds of category shifts appeared within its translation text, meanwhile the unit shift was indicated to be the most frequently used to translate the text.

Supatmiwati (2016) on also examined the Translation Shift of Verb and Sentence Style from English into Bahasa Indonesia. In this case, the research subject was the bilingual texts of Summary Report: MDG's Indonesia 2007 and its translation. However, the researcher only aim at figuring out the translation shift limited to the verb and sentence style within the text based on the shift level. In other words, this study did not obviously state the data collection technic although the researcher explained that his study only went through three methods; classification, analysis, and discussion. However, the given findings justified that passive style was the most common style used by Indonesia author in writing report or scientific article.

Another translation shift investigation was conducted by Hidayati (2016) focused on Unit Shift in Scarlet Sherlock Holmes' novel and its translation according to Catford's translation shift category. Describing the equivalence on its translation was applied to measure the effectiveness of the translation. She finally demonstrated that 8 types of unit shift occurred within, such as (1) word translated into phrase, (2) phrase into word, (3) phrase into sentence, (4) clause translated into word, (5) clause into phrase, (6) sentence translated into word, (7) sentence into phrase, (8) sentence translated into clause. Above all, words translated into phrases appeared about 230 data or $67,45 \%$ and identified to be the most frequently shifting strategy in it. Speaking on effectiveness, from 341 data, none of them were included to be non-equivalent which mean all types of translation shift were considered equivalence. 
Although those three previous studies above are the same in the case of object, however, this current studies tried to fill the gap in term of subject where it shed the light on exploring speech text as a formal text in Jokowi's speech regarding the translation shift from Indonesia as the source language to English as the target language. It is due to the fact that a very little research has been carried out in on speech text. These two previous studies indeed investigated novel and office official report which were identically different subject in context. Consequently, this study theoretically was expected to contribute in the development of translation studies and practically enlighten the translator understanding in doing translation process.

\section{RESEARCH METHOD}

This research subject was Jokowi's speech at the opening of the Annual Meetings Plenary of IMF-World Bank 2018 in Indonesia language as the source language and the English translation. The data of present study was words, phrases, and sentences which were taken from the official website of the Secretary Cabinet of Republic Indonesia for Indonesia speech transcript, while the English transcript was obtained through Portal Berita Infopublik which was also the official news platform of Indonesia managed by Directorate General of Information and Public Communication. The data collection was done in some steps follows; first, the reseacher read both Indonesia and English transcript of Jokowi's speech. Second, the researcher applied a note-taking strategy to classify the data based on its type. After that, the collected data was analysed using Catford's translation shift concept (1965) consisting two categories, level shift and category shift. Additionally, the category shift was later subdivided into four types of category including structure shift, class shift, unit shift, and intra-system shift.

\section{FINDINGS AND DISCUSSION}

As the researcher mentioned earlier, the data were collected from Indonesian-English sources of Jokowi's speech. The analysis of each data, furthermore, demonstrated speech text in both languages, Indonesia as the SL and English as TL. This study finally formulated findings as shown in on the following table below and together with the analysis of the findings of its kind of shifts occurred within such speech translation transcript:

Table 4.1. Speech translation transcript

\begin{tabular}{clc}
\hline No. & \multicolumn{1}{c}{ SHIFT } & TOTAL \\
\hline $\mathbf{1}$ & Level Shift & 3 \\
$\mathbf{2}$ & Category Shift & \\
& Structural Shift & 17 \\
& Class Shift & 34 \\
& Unit Shift & 17 \\
& $\cdot \quad$ Upward Rank Shift & 6 \\
& $\cdot \quad$ Downward Rank & \\
& $\quad$ Shift & 5 \\
\hline & Intra-system Shift & 5 \\
\hline
\end{tabular}

\section{Datum 1}

SL: Selamat datang di Bali,

\section{TL: Welcome to Bali}

The datum above showed that there was a unit shift occurred in terms of changing from the high to low unit (downward rank shift).

SL

TL

Selamat datang $($ phrase $) \rightarrow$ Welcome (word)

It could be seen that the word "selamat datang" in SL was classified as the noun phrase which was changed into only a word "welcome" in the TL. 
Therefore, it could be considered that the structure of noun phrase above was composed by using a noun as a word unit.

\section{Datum 2}

SL: Pertama-tama, atas nama masyarakat Indonesia, saya menyampaikan terima kasih atas perhatian...

TL: First of all, on behalf of the Indonesian people, let me extend my sincere gratitude for the attention...

From the datum above was found three translation shifts: First, there was a class shift occurred in the phrase "masyarakat Indonesia" in SL which was shifted from noun - noun into adjective - noun "Indonesian people" in TL.

SL

TL

Masyarakat Indonesia $\rightarrow$ Indonesian people

$$
\stackrel{\downarrow}{\downarrow} \quad \stackrel{\downarrow}{(\text { noun })}+\text { (noun) } \quad \text { (adjective) }+
$$

(noun)

Second, the grammatical structure of "saya menyampaikan" in SL was shifted into "let me extend" in TL. It was classified as the structural shift because the word order was changed from subject + verb into verb of agreement + object pronoun + verb 1 .

SL

TL

Saya menyampaikan terima kasih $\rightarrow$ Let me extend my sincere gratitude $\downarrow$

$$
\begin{aligned}
& \begin{array}{c}
\downarrow \\
(\text { subject })+(\text { verb })+\text { (noun })
\end{array} \\
& \text { (verb) }+(\text { object pronoun })+ \\
& \text { (noun) }
\end{aligned}
$$

Third, there was a rank shift from low to high unit (upward rank shift) shown by the word "terima kasih" in SL changed into the noun phrase "sincere gratitude" in TL.

SL

TL

Terima kasih (noun) $\rightarrow$ my sincere gratitude

$$
+(\text { noun })
$$

\section{Datum 3}

SL: Hal ini menunjukkan persaudaraan kita yang sangat erat...

TL: This shows our strong brotherhood

Based on Catford's concept, the structural changes of "persaudaraan kita yang sangat erat" in SL shifted into "our strong brotherhood" in TL. The phrase in SL consisted a noun phrase + an adjective phrase which was translated into the noun phrase consisting pronoun + adjective + noun . This shift in translation occurred because the linguistic structure of English noun phrase is syntactically different with Bahasa Indonesia as mentioned above it systematically constitutes noun + adjective.

SL

TL

Persaudaraan kita yang sangat erat $\rightarrow \quad$ Our strong brotherhood (persaudaraan kita $)+($ yang sangat erat)

(Noun Phrase) + (Adjective Phrase)

(Noun Phrase)

$($ noun + pronoun $)+($ adverb + adjective) (pronoun + adjective + noun)

\section{Datum 4}


SL: ... berkat langkah-langkah kebijakan moneter dan fiskal yang luar biasa, yang membutuhkan keberanian (politik) yang besar, bapak-Ibu para pembuat kebijakan telah menyelamatkan dunia dari depresi global...

TL: thanks to extraordinary fiscal and monetary policy measures, which required a big (political) courage, policy makers have saved the world from global depression...

From the datum above was found five translation shifts: First, there were the existence of a rank shift and a class shift in the word "berkat".

\section{SL TL}

Berkat (word) $\rightarrow$ Thanks to (phrase) (Preposition) (Noun phrase)

The rank shift occurred from low to high unit (upward rank shift) which was shifted from the word into the phrase "thanks to". Meanwhile, the class shift occurred because the word class of "berkat" was shifted from preposition to noun phrase which was classified as the class shift.

Second, there was the existence of structural shift shown by two noun phrases; those were "kebijakan moneter dan fiskal yang luar biasa" and "keberanian politik yang besar". The structures in SL were changed in TL due to the different linguistic system of Indonesian and English noun phrase.

SL

TL

kebijakan moneter dan fiskal yang luar biasa $\rightarrow$ extraordinary fiscal and monetary policy

(noun phrase $)+($ yang luar biasa $)$

(Noun Phrase)

(Adjective Phrase)

$$
\begin{aligned}
& (\text { noun }+ \text { noun })+(\text { adverb }+ \text { adjective }) \\
& \text { (adjective }+ \text { noun }+
\end{aligned}
$$

SL

\section{TL}

keberanian politik yang besar

$\rightarrow \quad$ a big political courage

(keberanian politik) + (yang luar biasa $)$

(Noun Phrase)

(noun phrase) + (adjective Phrase

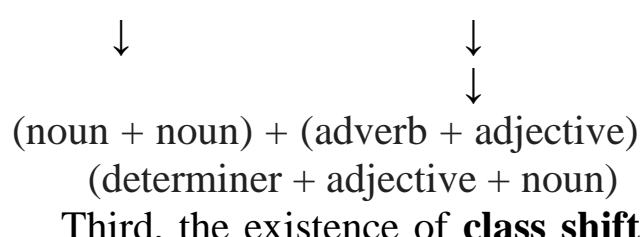

also occurred in the phrase "keberanian politik" in SL consisting of noun-noun which was shifted into adjective-noun "a political courage" in TL.

SL

TL

Keberanian Politik $\rightarrow$ A political courage

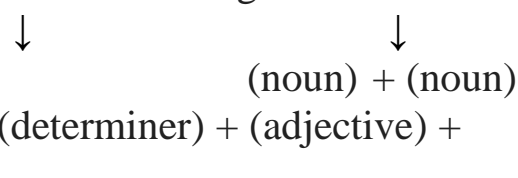

(noun)

Fourth, the datum above also showed the level shift translation. It can be concluded from the change of lexis "telah" in SL into the grammatical level "(have + verb 3)" in TL due to the difference of the grammatical order.

SL

\section{TL}

pembuat kebijakan telah menyelamatkan dunia $\rightarrow$ policy makers have saved the world

$$
\text { (have) }+(\text { verb } 3)
$$

Fifth, there was also the existence of intra-system shift shown by the phrase "para pembuat kebijakan" in SL which was shifted into "policy makers" in TL. The word "para" in Indonesia indicated the plural meaning as the use of $-\mathrm{s}$ in the end of the phrase "policy 
makers" also indicated the plural meaning in English.

SL

TL

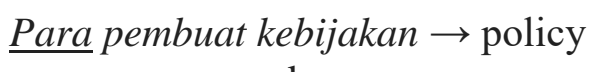
makers

\section{Datum 5}

SL: Dalam serial Game of Thrones, sejumlah "Great Houses", "Great Families", bertarung hebat antara satu sama lain untuk mengambil alih kendali "The Iron Throne"

TL: In the TV series "Game of Thrones", a number of Great Houses and Great Families are fiercely fighting each other to take control of the "the Iron Throne"

The datum above showed the existence of four types of translation shifts: First, there was the existence of a rank shift in the word "serial". The rank shift occurred from low to high unit (upward rank shift) in which the word "serial" in SL was shifted from the word into the phrase "the TV series" in TL.

SL

TL serial (word) $\rightarrow$ the TV series (phrase)

Second, the datum above also showed the level shift of translation. It can be concluded from the change of lexis "sejumlah" in SL into the grammatical level "(a- + noun) $=a$ number" in TL due to the difference of the grammatical order.

$$
\text { SL }
$$

TL

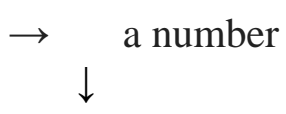

Sejumlah

$$
\text { (noun) }
$$

$($ determiner + noun $=$ noun phrase)

Third, the existence of class shift also occurred in the phrase "bertarung hebat" in SL consisting of verb-adverb which were shifted into adverb-verb "fiercely fighting" in TL.

SL

TL

bertarung hebat $\rightarrow$ fiercely fighting

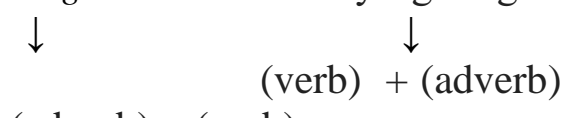

$$
\text { (adverb) }+(\text { verb })
$$

Fourth, the datum above showed that there was a unit shift occurred in terms of changing from the high to low unit (downward rank shift).

\section{SL}

TL

Mengambil alih (phrase) $\rightarrow$ take (word)

It could be seen that the word "mengambil alih" in SL was classified as the verb phrase which was changed into only a word "take" in the TL. Therefore, it could be considered that the structure of verb phrase above was composed by using a verb as a word unit.

\section{CONCLUSION}

In brief, this study gave an overview that all types of shift had the opportunity to occur in the TL text with exactly different frequency. In other words, referring to Table 1 mention above, it obviously highlighted that Category shift was the most dominant types applied as many 80 data in a total compared to Level Shift. However, these number of frequency was specifically split into four types of shift including Class Shift as first dominant types that most commonly used by translator as many as 34 data in a total and followed by Unit Shift with 24 data, also continued by structural shift with 17 data and the last types was intra-system shift with 5 data in a total.

After all, it provides additional evidence that translation shift is significantly inevitable due to grammatical and cultural differences 
between Indonesia and English or any other languages, in the absence of formal contact within translation activity for example in the case of formal text such Indonesia into English. These mandatory changes were introduced to maintain the purpose and effect of the ST in the TT. Despite the fact that Catford's translation shift theory is an old-fashioned strategy, however it is still widely used in nowadays translation agency or activity. Additionally the use of translation shift in this case was considerably effective since it could replace equivalent words, phrases and sentence with accurate meaning without losing its significant message from the SL to TL.

\section{REFERENCES}

Catford, J. C. (1965). A linguistic theory of translation: An Essay in Applied Linguistics. London: Oxford University Press.

Catford, J. C. (2000). A Linguistic Theory of Translation. In L. Venuti (Ed.), The Translation Studies Reader (1st Ed). New York: Routledge.

Falah, I. (2018). Remarks President Joko Widodo at the Opening of the Annual Meetings Plenary of IMF- WBG 2018_Unofficial English Translation. Portal Berita Info Publik. Retrieved from http://infopublik.id/kategori/amimf-wbg-2018/303200/remarkspresident-joko-widodo-at-theopening-of-the-annual-meetingsplenary-of-imf-wbg-2018unofficial-english-translation

Herman. (2014). Category Shifts In the English Translation of Harry
Potter and the Philosopher's Stone Movie Subtitle into Indonesia (An Applied Linguistics Study). IOSR Journal Of Humanities And Social Science, 19(12), 31-38. DOI: 10.9790/0837-191253138

Hidayati, N. (2016). A Translation Analysis of Unit Shift in 'A Study in Scarlet Sherlock Holmes' Novel and Its Translation. (Publication Article, Universitas Muhammadiyah Surakarta, Surakarta, Indonesia). Retrieved from http://eprints.ums.ac.id/

Munday, J. (2016). Introducing Translation Studies: Theories and Applications (4th ed.). Oxon \& New York: Routledge

Sekretariat Kabinet Republik Indonesia. (2018). Sambutan Presiden Joko Widodo pada Plenary Session IMF-World Bank Annual Meetings, 12 Oktober 2018, di Bali Nusa Dua Convention Center, Bali. Retrieved from https://setkab.go.id/sambutanpresiden-joko-widodo-padaplenary-session-imf-world-bankannual-meetings-12-oktober2018-di-bali-nusa-duaconvention-center-bali/

Supatmiwati, D. (2016). Translation Shift of Verb and Sentence Style from English into Bahasa Indonesian. Proceedings of Research, The Fourth International Conference On Education And Language (4th Icel) 2016. (pp. 257-259). Bandar Lampung: Universitas Bandar Lampung, Indonesia. 